\title{
Stepwise Utilization Process to Recover Valuable Components from Copper Slag
}

\author{
Siwei Li, Zhengqi Guo*, Jian Pan $\mathbb{1}$, Deqing Zhu, Tao Dong and Shenghu Lu \\ School of Minerals Processing and Bioengineering, Central South University, Changsha 410083, China; \\ swli@csu.edu.cn (S.L.); pjcsu@csu.edu.cn (J.P.); dqzhu@csu.edu.cn (D.Z.); dongtao@csu.edu.cn (T.D.); \\ lushenghu@csu.edu.cn (S.L.) \\ * Correspondence: guozqcsu@csu.edu.cn; Tel.: +86-731-8883-6041
}

Citation: Li, S.; Guo, Z.; Pan, J.; Zhu, D.; Dong, T.; Lu, S. Stepwise Utilization Process to Recover Valuable Components from Copper Slag. Minerals 2021, 11, 211. https://doi.org/10.3390/min11020211

Academic Editor: Kevin Galvin

Received: 18 December 2020

Accepted: 8 February 2021

Published: 17 February 2021

Publisher's Note: MDPI stays neutral with regard to jurisdictional claims in published maps and institutional affiliations.

Copyright: (c) 2021 by the authors. Licensee MDPI, Basel, Switzerland. This article is an open access article distributed under the terms and conditions of the Creative Commons Attribution (CC BY) license (https:// creativecommons.org/licenses/by/ $4.0 /)$.

\begin{abstract}
Waste copper slag is a typical hazardous solid waste containing a variety of valuable elements and has not been effectively disposed of so far. In this paper, a stepwise extraction process was proposed to recover valuable elements (copper, iron, lead and zinc) from waste copper slag. The specific procedures are as follows: (1) A flotation process was adopted to enrich copper, and when the copper grade in the flotation concentrate was $21.50 \%$, the copper recovery rate was $77.78 \%$. (2) The flotation tailings were pelletized with limestone, then the green pellets were reduced, and the magnetic separation process was carried out. When the iron and copper grades in the magnetic concentrate were $90.21 \% \mathrm{Fe}$ and $0.4 \% \mathrm{Cu}, 91.34 \%$ iron and $83.41 \%$ copper were recovered, respectively. (3) Non-magnetic tailings were mixed with clinker and standard sand to produce common Portland cement. Several products were obtained from the waste copper slag through the proposed process: flotation concentrate, measured $21.50 \% \mathrm{Cu}$; magnetic concentrate, containing $90.21 \% \mathrm{TFe}$ and $0.4 \%$ $\mathrm{Cu}$; direct reduction dust, including $65.17 \% \mathrm{ZnO}$ and $2.66 \% \mathrm{PbO}$; common Portland cement for building construction. The comprehensive utilization method for waste copper slag achieved zero tailing and has great potential for practical application.
\end{abstract}

Keywords: waste copper slag; flotation; direct reduction-magnetic separation; common Portland cement

\section{Introduction}

One of the greatest challenges in the mining and processing industries is waste management and waste copper slag is defined as one such waste [1]. Waste copper slag (WCS) is a by-product produced in the copper pyrometallurgical process. It is estimated that 30 million tons of WCS are generated and dumped globally every year [2,3]. In addition, the slag contains a lot of harmful elements, such as $\mathrm{Cu}, \mathrm{Pb}$ and $\mathrm{Zn}$, which cause pollution to the environment. These elements are not only non-biodegradable and toxic but also accumulate in human organisms, causing some physical disorders and health concerns [4-6]. Therefore, WCS is classified as hazardous waste [7-9]. Unfortunately, more than $80 \%$ of them are directly dumped without treatment, which may cause potential pollution $[10,11]$.

In order to comply with strict environmental regulations, numerous studies have been conducted to upgrade WCS, including building material [12]. However, this method usually has new contamination, such as the leachability of zinc, arsenic and antimony, and can only accommodate a very small fraction $[13,14]$.

Regarding the recovery of valuable metals from WCS, previous work has mainly focused on recycling elements from WCS using beneficiation, leaching and pyrometallurgical processes. These methods mainly include flotation [15,16], acid leaching [17,18], roasting followed by water leaching [19], bio-leaching [20] and direct reduction-magnetic separation or smelting reduction [21-23]. Roy et al. [15] adopted flotation to recover copper sulfide from copper smelter slag. The results show that under the optimal conditions, the 
recovery rate of copper sulfide reached $84.82 \%$. There is no doubt that flotation can recover copper sulfide to a certain extent. However, the copper oxide within it cannot be recovered. Muhammad et al. [18] employed sulfuric acid to extract metals from copper-rich converter slag. A copper precipitation rate of $90 \%$ can be obtained. At the same time, the iron extraction rate is only slightly higher than 60\%. Mikoda et al. [20] used acidithiobacillus thiooxidans to leach valuable metals from copper metallurgical slag. The extraction rate of rare earth element (REE) and Co can reach more than $90 \%$. However, the process duration is too long. Physical beneficiation and hydrometallurgical process can efficiently extract $\mathrm{Cu}, \mathrm{Pb}, \mathrm{REE}$, etc. However, these processes cannot effectively recover iron as the main element in copper slag.

The pyrometallurgical process is generally used to recover iron from copper slag [24]. Smelting reduction is a deep reduction process; during this process, $\mathrm{FeO}$ is reduced to pig iron by a reductant at a high temperature above $1450{ }^{\circ} \mathrm{C}$ [1]. It can obtain a high iron recovery rate, but shortens the use time of the kiln. It is effective to recover iron from copper slag (CS) by direct reduction-magnetic separation. By reducing CS at $1200-1300{ }^{\circ} \mathrm{C}$, fayalite and copper sulfide can be transformed into metallic iron and copper, and then Fe-Cu alloy phase can be formed [25]. Subsequently, a magnetic separation process is used to recover the Fe-Cu alloy. However, magnetic separation tailings have not been effectively used.

In this paper, a comprehensive process for recovering valuable metals from WCS is developed. The main steps of the proposed process include flotation to enrich $\mathrm{Cu}$ and direct reducing-magnetic separation to produce crude Fe-Cu alloy, and subsequent non-magnetic tailings to replace clinker to produce common Portland cement. Meanwhile, lead and zinc were recovered as dust through this process. No tailings were produced during the entire process, indicating that this is a clean and green process.

\section{Materials and Methods}

\subsection{Materials}

The WCS used in this study was supplied by Anhui Province, China. The chemical composition of WCS is shown in Table 1 . The WCS contains $39.54 \% \mathrm{Fe}, 0.81 \% \mathrm{Cu}$ and $32.11 \% \mathrm{SiO}_{2}$. Meanwhile, the contents of $\mathrm{Pb}$ and $\mathrm{Zn}$ are $0.12 \%$ and $2.35 \%$, respectively, which can be volatilized from the reduction process. As shown in Figure 1, the main mineral phases of copper slag are magnetite $\left(\mathrm{Fe}_{3} \mathrm{O}_{4}\right)$ and fayalite $\left(\mathrm{Fe}_{2} \mathrm{SiO}_{4}\right)$. The microstructure of the copper slag was observed by SEM-EDS, and the result is shown in Figure 2. It can be seen from Figure 2 that iron mainly exists in the form of fayalite $\left(\mathrm{Fe}_{2} \mathrm{SiO}_{4}\right)$ and magnetite $\left(\mathrm{Fe}_{3} \mathrm{O}_{4}\right)$, while copper mainly exists in the form of matte $\left(\mathrm{Cu}_{2} \mathrm{~S}\right)$. Meanwhile, iron minerals and copper minerals exist as independent particles, which facilitates the recovery of copper through the flotation process.

Table 1. Chemical composition of waste copper slag (wt.\%).

\begin{tabular}{lccccccccccc}
\hline TFe & $\mathrm{FeO}$ & $\mathrm{SiO}_{2}$ & $\mathrm{CaO}$ & $\mathrm{MgO}$ & $\mathrm{Al}_{2} \mathrm{O}_{3}$ & $\mathrm{Cu}$ & $\mathbf{P b}$ & $\mathrm{Zn}$ & $\mathbf{S}$ & $\mathbf{P}$ & $\begin{array}{c}\text { LOI } \\
*\end{array}$ \\
\hline 39.54 & 40.96 & 32.11 & 2.78 & 1.65 & 3.34 & 0.81 & 0.12 & 2.35 & 0.48 & 0.11 & 1.02 \\
\hline${ }^{*}$ Loss on ignition.
\end{tabular}




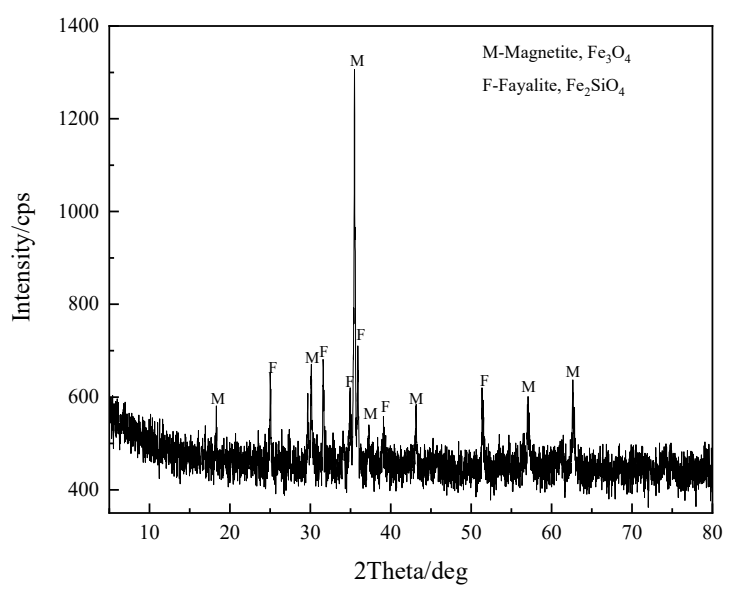

Figure 1. XRD pattern of waste copper slag.

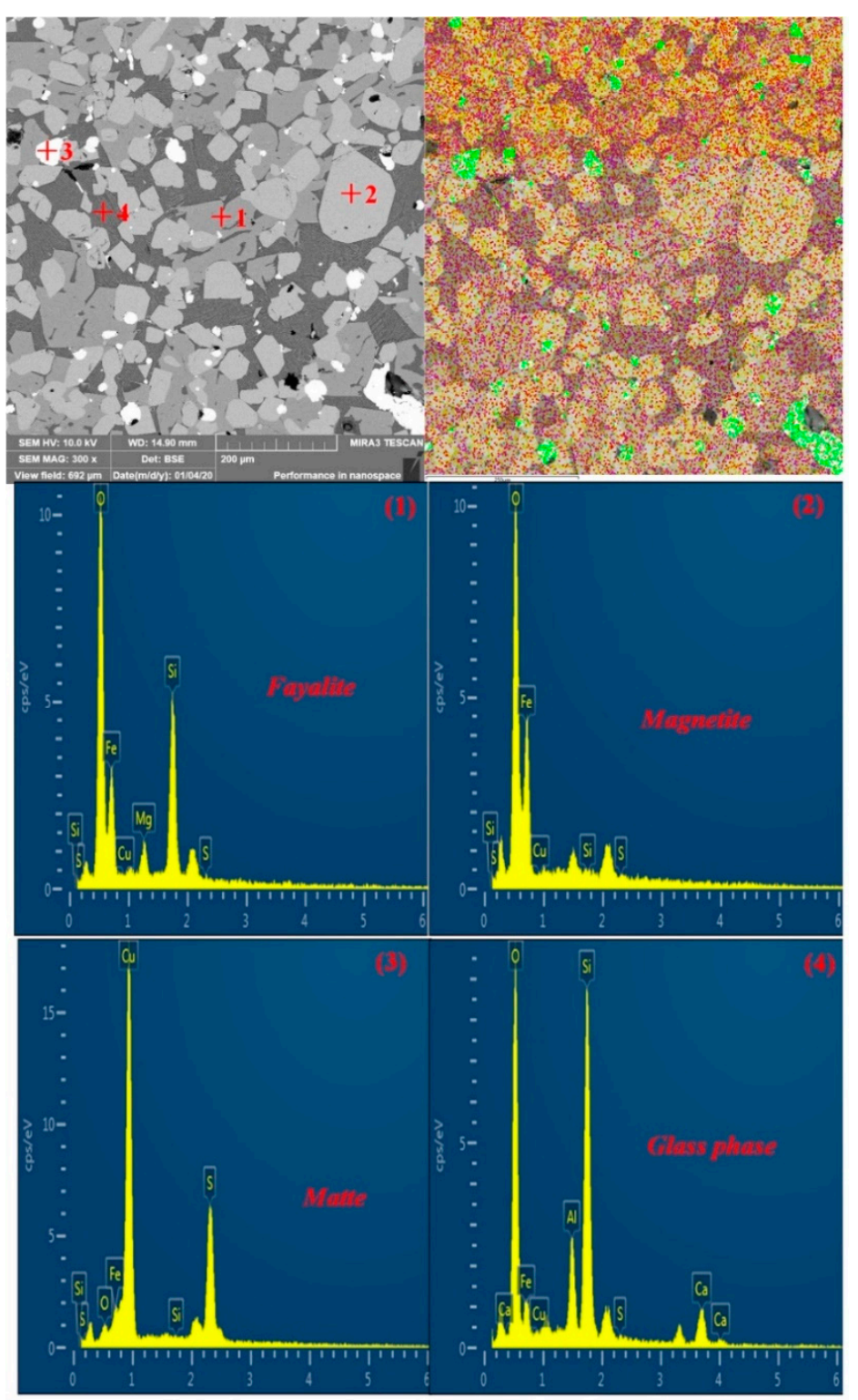

Figure 2. Microstructure of waste copper slag.(1, 2, 3, 4 represent mean points, element content in Table 2). 
Table 2. Element content of Figure 2.

\begin{tabular}{|c|c|c|c|c|c|c|c|c|c|c|}
\hline Point & $\mathrm{Fe}$ & $\mathrm{Cu}$ & $S$ & Si & $\begin{array}{c}\text { ement/v } \\
O\end{array}$ & $\mathrm{Mg}$ & Al & $\mathrm{Ca}$ & $\mathrm{Na}$ & Minerals \\
\hline 1 & 49.15 & 0 & 0.25 & 16.18 & 31.55 & 2.87 & 0 & 0 & 0 & Fayalite \\
\hline 2 & 70.32 & 0 & 0.05 & 0.59 & 29.04 & 0 & 0 & 0 & 0 & Magnetite \\
\hline 3 & 11.81 & 62.92 & 22.31 & 0.07 & 2.88 & 0 & 0 & 0 & 0 & Matte \\
\hline 4 & 14.14 & 0 & 0.38 & 29.34 & 42.61 & 0 & 6.35 & 7.18 & 0 & $\begin{array}{l}\text { Glass } \\
\text { phase }\end{array}$ \\
\hline
\end{tabular}

\subsection{Methods}

The flow chart of the proposed WCS treatment process is presented in Figure 3, which was developed based on the basic understanding of the following steps: (1) the WCS is enriched with $\mathrm{Cu}$ by a flotation process; (2) direct reduction-magnetic separation of flotation tailing pellets to prepare $\mathrm{Fe}-\mathrm{Cu}$ alloy and to remove $\mathrm{Pb}$ and $\mathrm{Zn}$; (3) non-magnetic tailing to prepare Portland cement to achieve zero tailings. The experimental details of each step are described as follows.

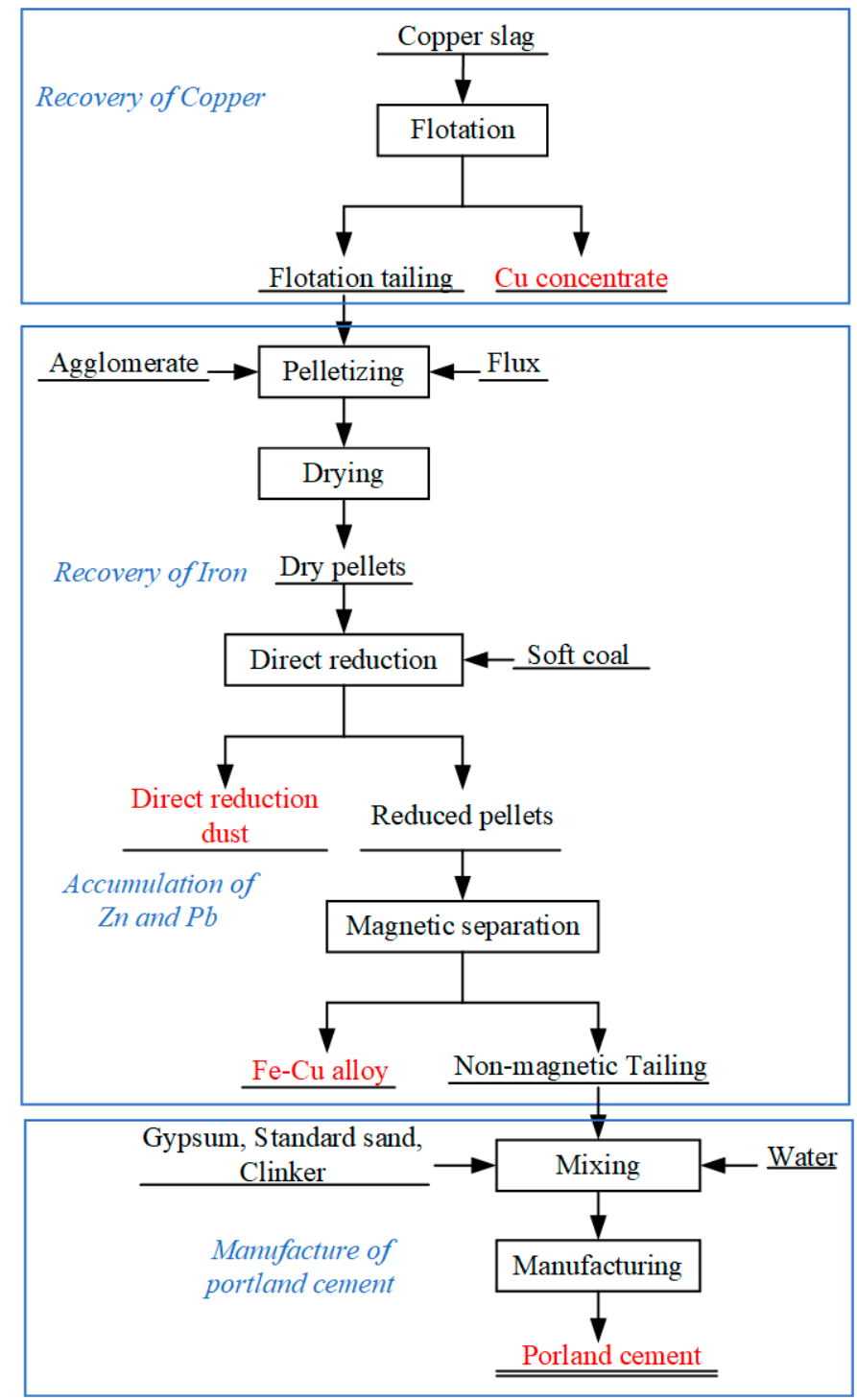

Figure 3. Experiment flow chart of the proposed process. 


\subsubsection{Flotation Process to Recover $\mathrm{Cu}$}

The flotation tests were carried out in a 0.75 L XFD laboratory flotation cell (FGC5-35, Yunhao Mining and Metallurgical Equipment Co., Ltd., Wuhan, China). In all flotation tests, a $500 \mathrm{~g}$ sample was used, the impeller speed was set to $600 \mathrm{rpm}$ and the aeration rate was $0.2 \mathrm{dm}^{3} / \mathrm{min}$. The specific operation of the flotation tests is outlined in Figure 4. In the flotation process, analytical grade Butyl xanthate $\left(\mathrm{C}_{5} \mathrm{H}_{10} \mathrm{OS}_{2}\right)(\mathrm{g} / \mathrm{t})$ and terpene oil $\left(\mathrm{C}_{10} \mathrm{H}_{18} \mathrm{O}\right)(\mathrm{g} / \mathrm{t})$ were used as collector and frother, respectively [7]. The recovery rate of copper is calculated as follows:

$$
\eta_{C u}=\frac{w_{1}}{w_{0}} \times y \times 100 \%
$$

where $\eta_{C u}$ is the recovery rate of copper; $w_{1}$ and $w_{0}$ are the copper grades in the flotation concentrate and raw material, respectively; $y$ is the yield of the flotation concentrate.

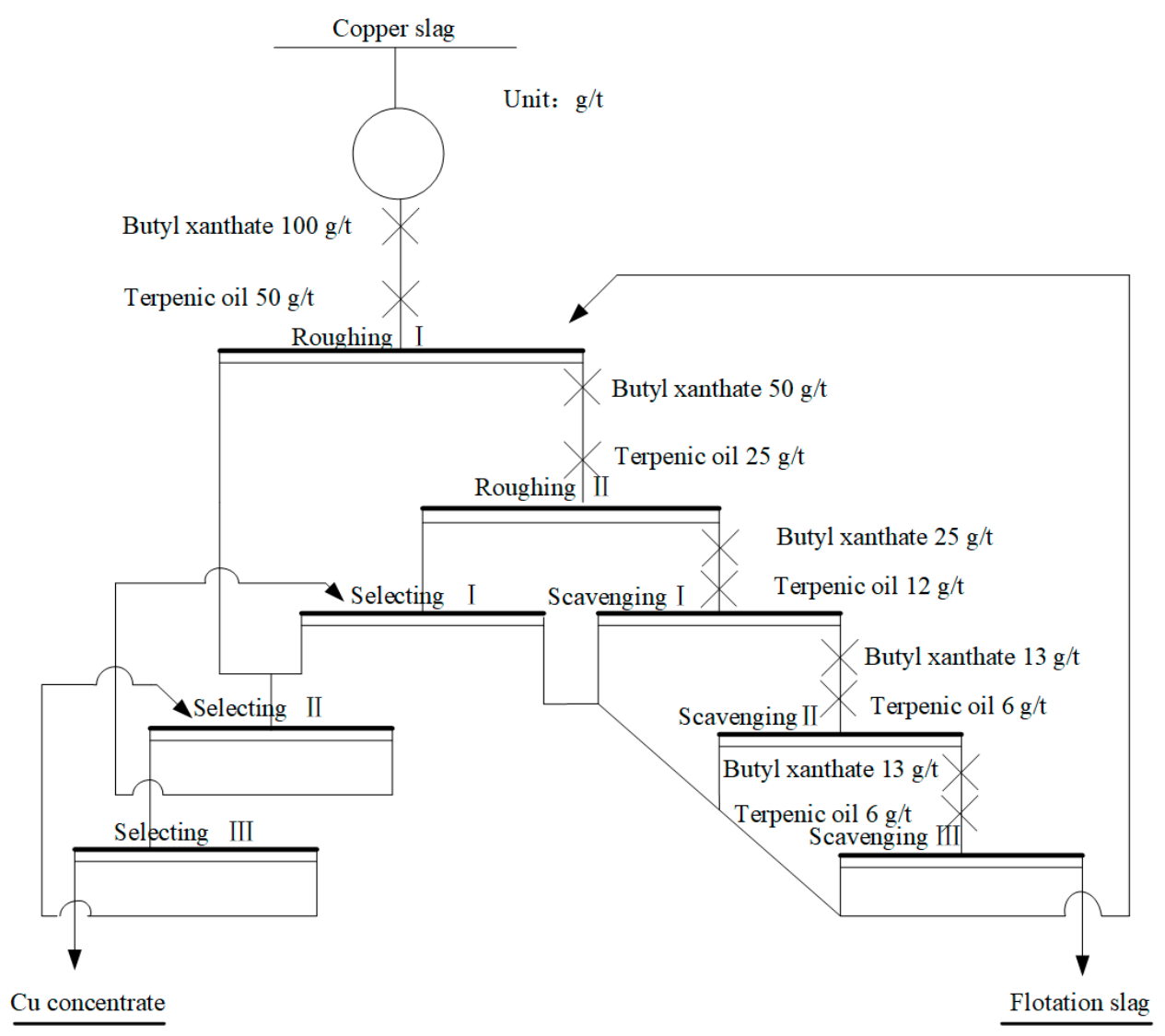

Figure 4. Schematic diagram of the flotation process.

\subsubsection{Preparation of Crude Fe-Cu Alloy by Direct Reduction-Magnetic Separation}

The flotation tailings and flux were fully mixed, and then the mixture was pressed into cylindrical briquettes (height: $10 \mathrm{~mm}$ and diameter: $10 \mathrm{~mm}$ ). The briquettes were dried at $110{ }^{\circ} \mathrm{C}$ for $4 \mathrm{~h}$.

The direct reduction tests were performed in a muffle furnace at $1250{ }^{\circ} \mathrm{C}$ for $80 \mathrm{~min}$. For the reduction test, $60 \mathrm{~g}$ briquettes were mixed with $120 \mathrm{~g}$ soft coal (ash content: $4.49 \%$; production location: Shenfu) $(1-5 \mathrm{~mm})$ and then encased into a corundum crucible with a depth of $80 \mathrm{~mm}$ and diameter of $80 \mathrm{~mm}$. [21]. After reduction, the reduced briquettes were cooled to room temperature for the subsequent magnetic separation process. The specific 
operation process of magnetic separation is outlined in reference [26]. The metal recovery rate (iron or copper) is calculated as follows:

$$
\eta=\frac{w^{\prime}}{w} \times y_{1} \times 100 \%
$$

where $\eta$ is the metal recovery rate (iron or copper); $w^{\prime}$ and $w$ are the iron (or copper) grades in the magnetic separation concentrate and reduced pellets, respectively; and $y_{1}$ is the yield of the concentrate.

The volatilization rate of zinc (or lead) is calculated as follows:

$$
\gamma=\left(100-\frac{w_{2}}{w_{3}} \times y_{2}\right) \times 100 \%
$$

where $\gamma$ is the volatilization rate of zinc (or lead); $w_{2}$ and $w_{3}$ are the content of zinc (or lead) in the reduced pellets and flotation, respectively; and $y_{2}$ is the yield of reduced pellets.

\subsubsection{Production of Common Portland Cement}

A certain proportion of non-magnetic material (NMT), clinker and gypsum were thoroughly mixed. Ingredients of Portland cement are shown in Table 3.

Table 3. Ingredients of Portland cement/\%.

\begin{tabular}{cccccc}
\hline Sample & $\begin{array}{c}\text { Non-Magnetic } \\
\text { Tailing }\end{array}$ & Gypsum & Clinker & $\begin{array}{c}\text { Standard } \\
\text { Sand/Cement Ratio }\end{array}$ & $\begin{array}{c}\text { Water/Cement } \\
\text { Ratio }\end{array}$ \\
\hline PC0 & 0 & 5 & 95 & 9 & 0.5 \\
PC6 & 6 & 5 & 89 & 9 & 0.5 \\
PC9 & 9 & 5 & 86 & 9 & 0.5 \\
PC12 & 12 & 5 & 83 & 9 & 0.5 \\
PC15 & 15 & 5 & 80 & 9 & 0.5 \\
\hline
\end{tabular}

The mixtures were cast into steel molds (cuboid) in three layers and compacted using a vibrating table [27]. All samples were stored in the ambient environment under a plastic sheet, and then the samples were demolded and wet-cured until the test date. The samples were cured at room temperature $\left(18-22{ }^{\circ} \mathrm{C}\right)$ for 3 and 28 days separately. Concrete cuboids with a size of $40 \times 40 \times 160 \mathrm{~mm}$ were cast for the compressive strength test (Equipment: Universal testing machine, KY-D2305, Jilin Province Jilin Test Technology Co., Ltd., Jilin, China).

\subsection{Characterization of Raw Materials and Products}

The chemical compositions of WCS, flotation slag, Fe-Cu alloy and non-magnetical material tailings were measured by X-ray fluorescence spectroscopy (XRF, PANalytical Axios mAX, PANalytical B, V., Almelo, The Netherlands). The microstructure of reduced briquettes was observed and characterized by scanning electron microscopy (SEM) (TESCAN, MIRA3, LMH, FEI, Eindhoven, The Netherlands) and energy-dispersive spectrometry (EDS) (XMAX20, FEI, Eindhovern, The Netherlands). The mineral phases of WCS, flotation tailing, direct reduction dust and reduced briquettes were measured by X-ray powder diffraction (XRD, RIGAKU, D/Max-2500, Bruker corporation, Madison, WI, USA) with a $2 \theta$ scan range from $10^{\circ}$ to $80^{\circ}$. The compressive strength of the Portland cement was measured according to the national standard (GB/T 175-2007).

\section{Results and Discussion}

\subsection{Flotation Process to Enrich Cu in Waste Copper Slag}

Table 4 lists the chemical composition of the flotation concentrates and tailings. When the overall copper recovery rate was $77.78 \%$, the $\mathrm{Cu}$ content of the flotation concentrate was $21.50 \%$. In addition, the contents of $\mathrm{Fe}_{\text {total }}$ and $\mathrm{SiO}_{2}$ in the concentrate were higher, 
wth values are $28.22 \%$ and $21.33 \%$, respectively. Meanwhile, the contents of $\mathrm{S}, \mathrm{Pb}$ and $\mathrm{Zn}$ were $10.15 \%, 0.77 \%$ and $0.72 \%$, respectively. The contents of $\mathrm{Fe}, \mathrm{SiO}_{2}, \mathrm{~Pb}$ and $\mathrm{Zn}$ of the tailings were $39.88 \%, 32.44 \%, 0.1 \%$ and $2.4 \%$, respectively. The size distribution of the $\mathrm{Cu}$ concentrate and flotation tailings is presented in Figure $5 \mathrm{a}, \mathrm{b}$. It can be seen that their particle size is fine, and $80 \%$ pass $100 \mu \mathrm{m}$.

Table 4. Chemical compositions of the flotation concentrate and tailings (wt.\%).

\begin{tabular}{cccccccccc}
\hline Sample & $\mathrm{TFe}$ & $\mathrm{SiO}_{2}$ & $\mathrm{CaO}$ & $\mathbf{M g O}$ & $\mathrm{Al}_{2} \mathbf{O}_{3}$ & $\mathbf{C u}$ & $\mathbf{P b}$ & $\mathbf{Z n}$ & $\mathbf{S}$ \\
\hline Raw WCS & 39.54 & 32.11 & 2.78 & 1.65 & 3.34 & 0.81 & 0.12 & 2.35 & 0.48 \\
Concentrate & 28.22 & 21.33 & 2.34 & 1.02 & 1.71 & 21.50 & 0.77 & 0.72 & 10.15 \\
Tailing & 39.88 & 32.44 & 2.79 & 1.67 & 3.39 & 0.25 & 0.1 & 2.4 & 0.19 \\
\hline
\end{tabular}

(a)

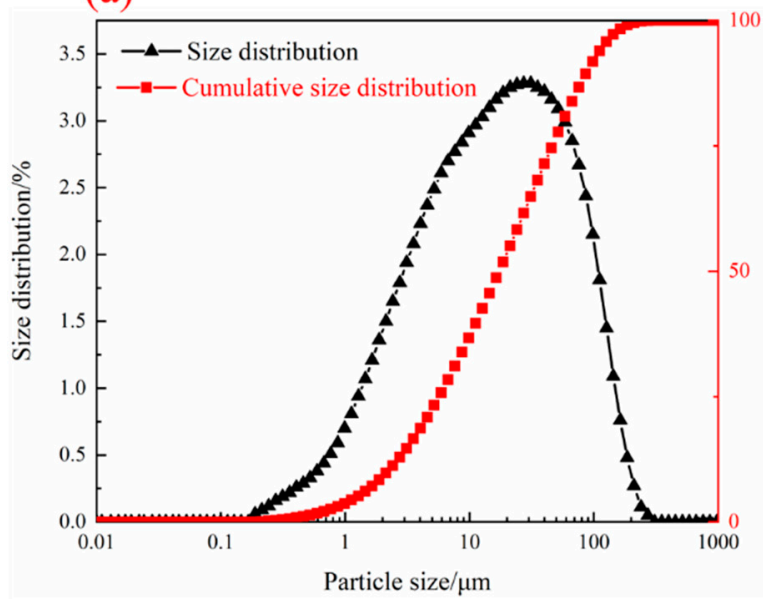

(b)

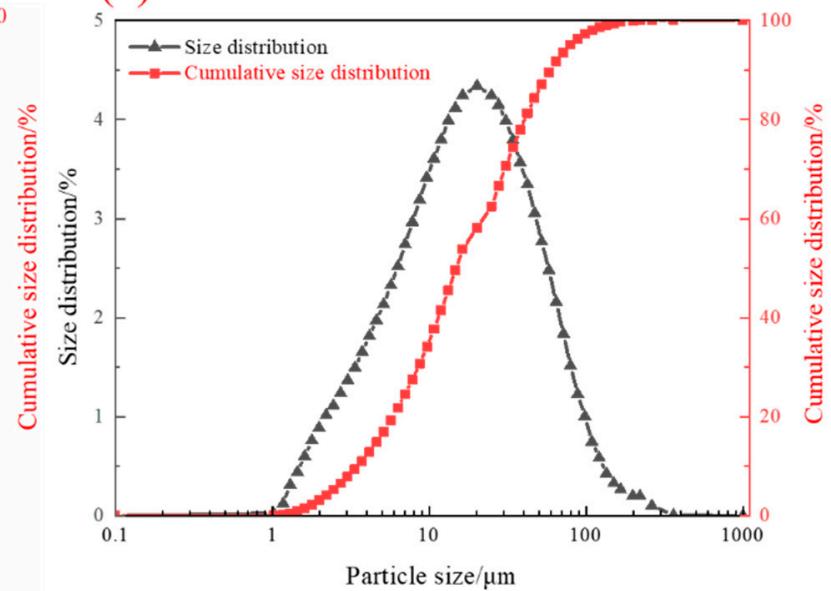

Figure 5. Size distributions of $\mathrm{Cu}$ concentrate and flotation tailings (a) Cu concentrate, (b) flotation tailings.

The XRD patterns of the $\mathrm{Cu}$ concentrate and tailings are shown in Figure 6a,b. It indicates that iron in the flotation tailings mainly exists in the form of fayalite $\left(\mathrm{Fe}_{2} \mathrm{SiO}_{4}\right)$ and magnetite $\left(\mathrm{Fe}_{3} \mathrm{O}_{4}\right)$. The microstructure of copper concentrate was observed by SEM-EDS, and the results are shown in Figure 7a-d. It can be seen from Figure 7 that chalcopyrite $\left(\mathrm{CuFeS}_{2}\right)$ and copper sulfide $\left(\mathrm{Cu}_{2} \mathrm{~S}\right)$ are the main mineral phases of copper-bearing with a particle size of less than $50 \mu \mathrm{m}$.
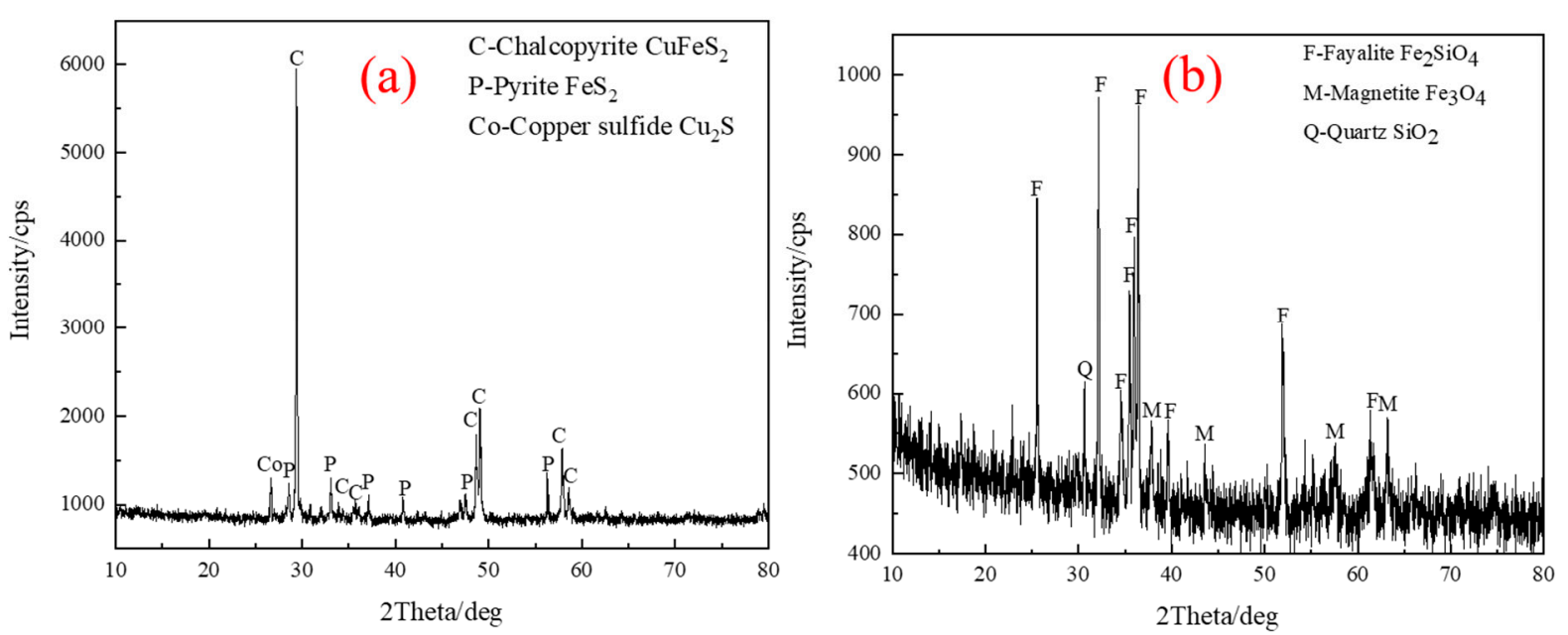

Figure 6. XRD of $\mathrm{Cu}$ concentrate and flotation tailings (a) Cu concentrate, (b) flotation tailings. 


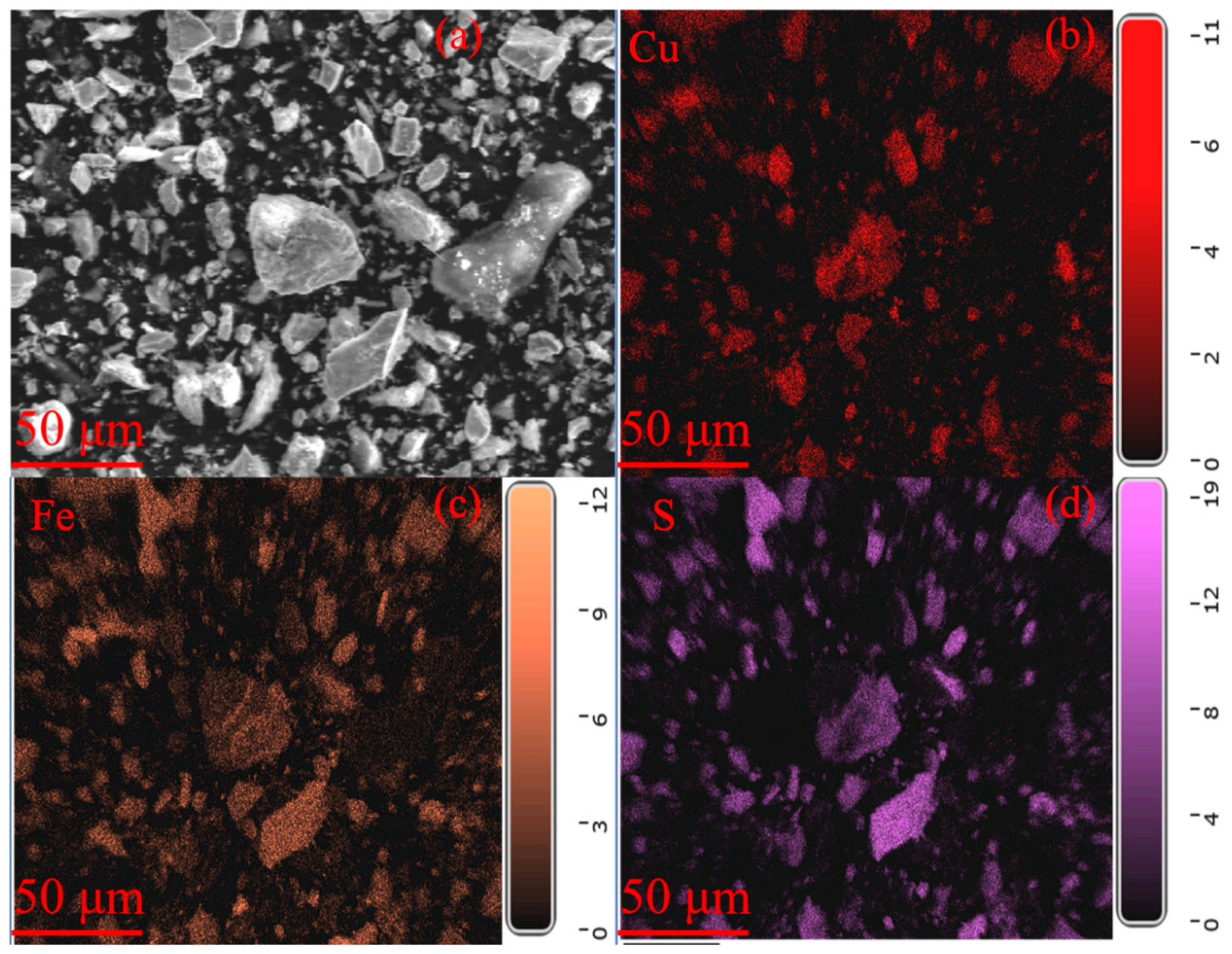

Figure 7. SEM-EDS of $\mathrm{Cu}$ concentrate $(\mathbf{a})$ is the original SEM, $(\mathbf{b}-\mathbf{d})$ are the mapping scanning of copper, iron and sulfur, respectively).

\subsection{Direct Reduction-Magnetic Process to Recover Fe, $\mathrm{Cu}, \mathrm{Pb}$ and $\mathrm{Zn}$}

According to Figure 6, the main phases of flotation tailings are fayalite and magnetite. The reduction of magnetite, fayalite and pyrite has been investigated in previous research $[10,21,23]$. These studies have shown that it is difficult to reduce fayalite with $\mathrm{CO}$ and that it can only be reduced by carbon at high temperatures. In the presence of $\mathrm{CaO}$, fayalite is more easily reduced by $\mathrm{C}$ and $\mathrm{CO}$. Pyrite and copper sulfide are difficult to be reduced by solid carbon to form metallic iron and copper. Adding $\mathrm{CaO}$ can reduce the required Gibbs free energy of pyrite and copper sulfide reduction.

Figure 8 presents the effect of additive dosage on the recovery of Fe and $\mathrm{Cu}$ and the volatilization of $\mathrm{Zn}$ and $\mathrm{Pb}$. Without additives, the recovery rates of iron and copper are only $72.87 \%$ and $65.34 \%$, respectively. Meanwhile, the iron grade of magnetic concentrate is $78.62 \%$. Compared with no additives, in the presence of $20 \%$ additive, the recovery rates of iron and copper are $91.34 \%$ and $83.41 \%$, respectively, and the grade of iron is $90.21 \%$, and the content of copper is maintained at $0.34 \%$. When the additives are $20 \%$ and $0 \%$, the volatilization rates of zinc and lead are $98.89 \%$ and $95.33 \%$, and $89.6 \%$ and $86.33 \%$, respectively. Increasing the dosage to $25 \%$ has a slight effect on the indexes. From the above, it is recommended to add $20 \%$ as the best additive dosage. 


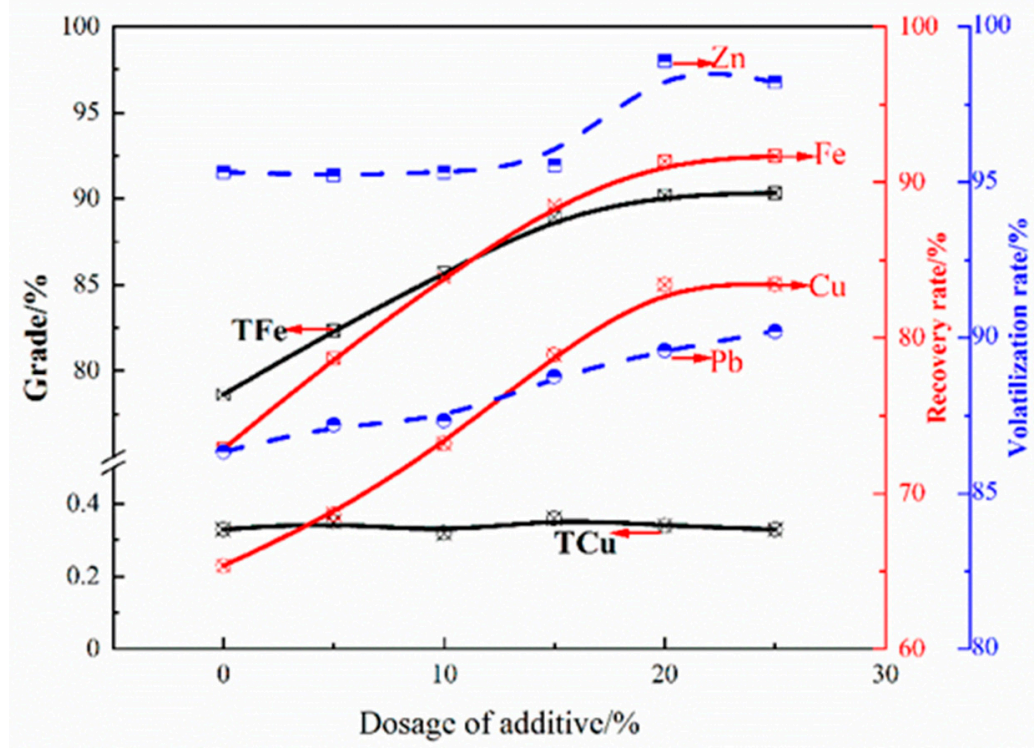

Figure 8. Effect of additive dosage on recovery of $\mathrm{Fe}, \mathrm{Cu}, \mathrm{Zn}$ and $\mathrm{Pb}$ (reduction at $1250{ }^{\circ} \mathrm{C}$ for $80 \mathrm{~min}$ at $\mathrm{C} / \mathrm{Fe}$ mass ratio of $2,0.3$ basicity).

The XRD patterns of the roasted briquettes obtained under different additive dosages are presented in Figure 9. It can be seen from Figure 9 that during the reduction process, the peak intensity of iron is enhanced in the presence of additives, which is caused by the iron grain growing. Figure 10 shows the electron probe microanalysis (EPMA) of roasted briquettes with $20 \%$ additives. The roasted briquettes contain two parts,:one part is $\mathrm{Fe}-\mathrm{Cu}$ alloy, and the other part is gangue. Most of the copper is combined with iron to form Fe-Cu alloy. Meanwhile, the boundary between the alloy and the gangue is obvious, which facilitates the recovery of iron and copper through the grinding process.

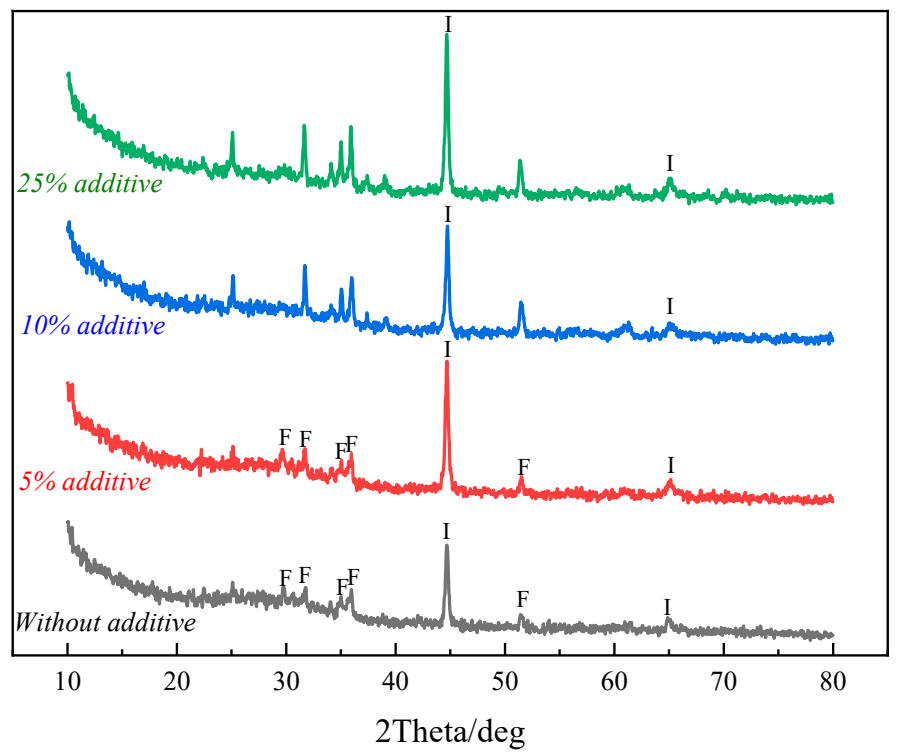

Figure 9. XRD patterns of reduced pellets obtained at the different additive dosages. 

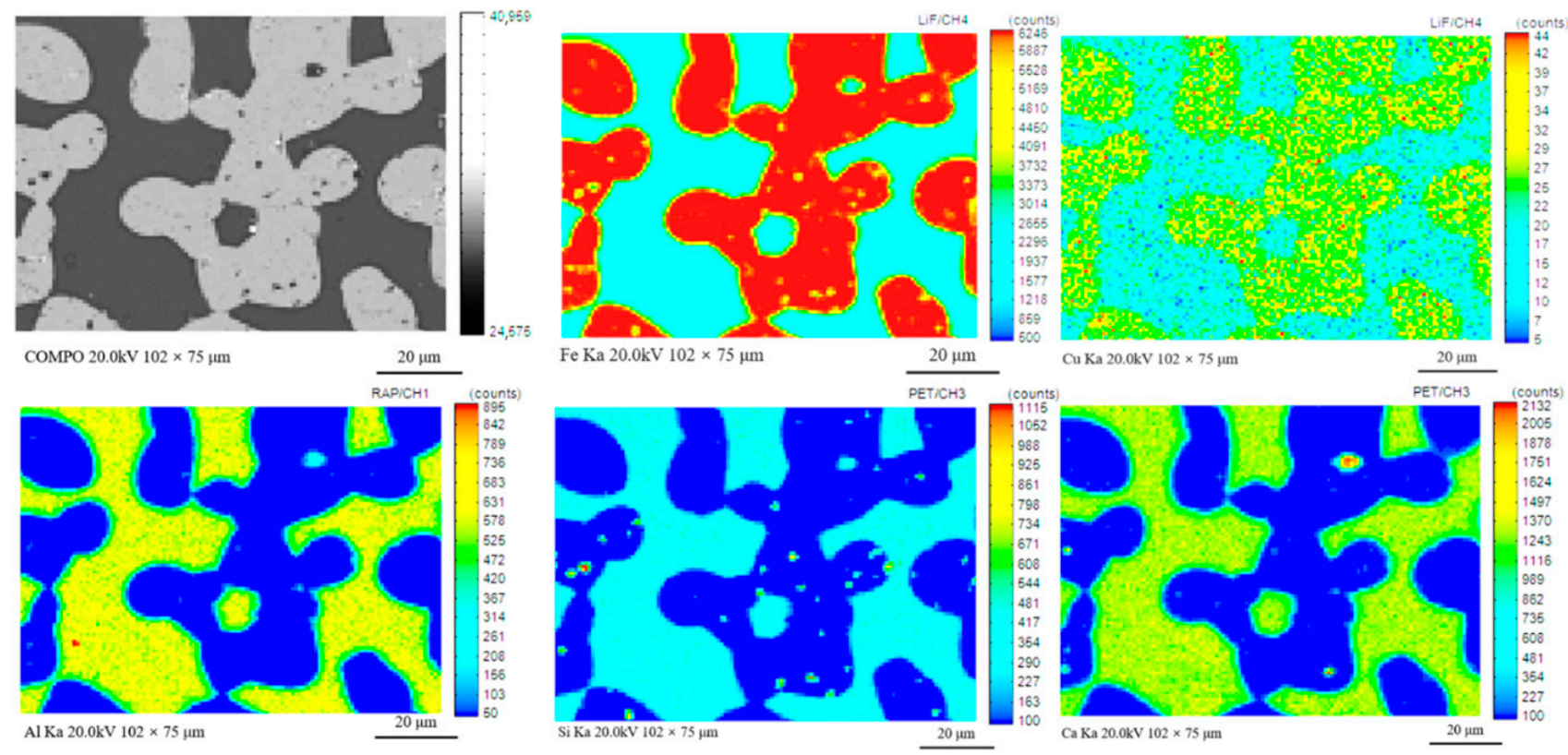

Figure 10. Electron probe microanalysis (EPMA) of reduced pellets with $20 \%$ additives (F: Fayalite $\mathrm{Fe}_{2} \mathrm{SiO}_{4}$; $\mathrm{I}: \mathrm{Iron} \mathrm{Fe}$ ).

Reduction was performed at $1250{ }^{\circ} \mathrm{C}$ for 80 min under the conditions of $\mathrm{C} / \mathrm{Fe}$ mass ratio of 2 , the basicity of 0.3 and additive dosages of $20 \%$. The chemical compositions of the Fe-Cu alloy obtained at $20 \%$ additive are presented in Table 5 . It can be seen that the Fe-Cu alloy contains $90.21 \%$ of TFe and $0.4 \%$ of $\mathrm{Cu}$, and the contents of $\mathrm{S}$ and $\mathrm{P}$ are only $0.032 \%$ and $0.025 \%$, respectively, which can be used as a burden for the weather resistance steelmaking. The results further confirm that the direct reduction-magnetic separation process is an effective means to upgrade the WCS.

Table 5. Chemical compositions of Fe-Cu alloy obtained with $20 \%$ additives.

\begin{tabular}{ccccccccccc}
\hline Sample & $\mathbf{T F e}$ & $\mathrm{SiO}_{2}$ & $\mathbf{C a O}$ & $\mathbf{M g O}$ & $\mathrm{Al}_{2} \mathbf{O}_{3}$ & $\mathbf{C u}$ & $\mathbf{P b}$ & $\mathbf{Z n}$ & $\mathbf{S}$ & $\mathbf{P}$ \\
\hline Fe-Cu alloy & 90.21 & 3.32 & 0.89 & 0.24 & 0.32 & 0.4 & 0.044 & 0.021 & 0.032 & 0.025 \\
\hline
\end{tabular}

The chemical compositions of the direct reduction dust are shown in Table 6. The main compositions of dust are $65.17 \% \mathrm{ZnO}$ and $2.66 \% \mathrm{PbO}$, which can be used as raw materials for extracting zinc. Many studies have been carried out on the comprehensive utilization of secondary zinc oxide $[28,29]$. Therefore, the treatment of reduction dust are not discussed in this paper.

Table 6. Chemical compositions of dust/wt.\%.

\begin{tabular}{cccccccccc}
\hline Sample & $\mathrm{ZnO}$ & $\mathrm{PbO}$ & $\mathrm{C}$ & $\mathrm{SiO}_{2}$ & $\mathrm{CaO}$ & $\mathrm{MgO}$ & $\mathrm{Al}_{2} \mathrm{O}_{3}$ & $\mathrm{Na}_{2} \mathrm{O}$ & $\mathrm{S}$ \\
\hline Dust & 65.17 & 2.66 & 8.99 & 1.78 & 0.09 & 0.14 & 0.22 & 0.56 & 2.19 \\
\hline
\end{tabular}

\subsection{Preparation of Portland Cement from Non-Magnetic Tailings}

The chemical composition of non-magnetic tailings is listed in Table 7. The nonmagnetic tailings include $55.64 \% \mathrm{SiO}_{2}$ and $16.83 \% \mathrm{CaO}$, and the contents of $\mathrm{Cu}, \mathrm{Pb}$ and $\mathrm{Zn}$ are $0.01 \%, 0.06 \%$ and $0.02 \%$, respectively. According to the USEPA standard, the toxicity characteristics of the non-magnetic tailings were determined by the leaching procedure tests, and the results are shown in Table 8. The concentrations of $\mathrm{Cu}^{2+}, \mathrm{Pb}^{2+}$ and $\mathrm{Zn}^{2+}$ in the leachate are $0.021 \mathrm{mg} / \mathrm{L}, 0.001 \mathrm{mg} / \mathrm{L}$ and $0.046 \mathrm{mg} / \mathrm{L}$, respectively, which are lower than the critical value, indicating that the non-magnetic tailings harmless and can be used directly as the burden for preparing cement. 
Table 7. Chemical compositions of non-magnetic tailings/wt.\%.

\begin{tabular}{ccccccccccc}
\hline Sample & $\mathbf{T F e}$ & $\mathrm{SiO}_{2}$ & $\mathbf{C a O}$ & $\mathbf{M g O}$ & $\mathrm{Al}_{2} \mathbf{O}_{3}$ & $\mathbf{C u}$ & $\mathbf{P b}$ & $\mathbf{Z n}$ & $\mathbf{S}$ & $\mathbf{P}$ \\
\hline Tailing & 9.62 & 55.64 & 16.83 & 2.91 & 5.99 & 0.01 & 0.06 & 0.02 & 0.15 & 0.18 \\
\hline
\end{tabular}

Table 8. Toxicity Characteristics of Leaching Procedure (TCLP) test results of non-magnetic tailings $/ \mathrm{mg} / \mathrm{L}$.

\begin{tabular}{cccc}
\hline Elements & $\mathbf{C u}$ & $\mathbf{P b}$ & $\mathbf{Z n}$ \\
\hline Tailing & 0.021 & 0.001 & 0.046 \\
Toxicity thresholds & 100 & 5 & 100 \\
\hline
\end{tabular}

Figure 11 and Table 9 present the particle size distributions of non-magnetic tailings obtained from different ball-milling times. It can be seen that after ball milling the original sample for $1 \mathrm{~h}, 90 \%$ of the powder is less than $30 \mu \mathrm{m}$. When ball milling was extended to $3 \mathrm{~h}$, the particle size changed slightly. When the ball milling time was further extended to $4 \mathrm{~h}$, the powder agglomerated, and the particle size D90 increased. The specific surface area (SSA) increased from $1.03 \mathrm{~g} / \mathrm{cm}^{2}$ to $2.73 \mathrm{~g} / \mathrm{cm}^{2}$. Considering the cost, it is recommended to use a ball milling of $2 \mathrm{~h}$. The samples obtained from the ball milling for $2 \mathrm{~h}$ were applied as raw materials for cement manufacturing.

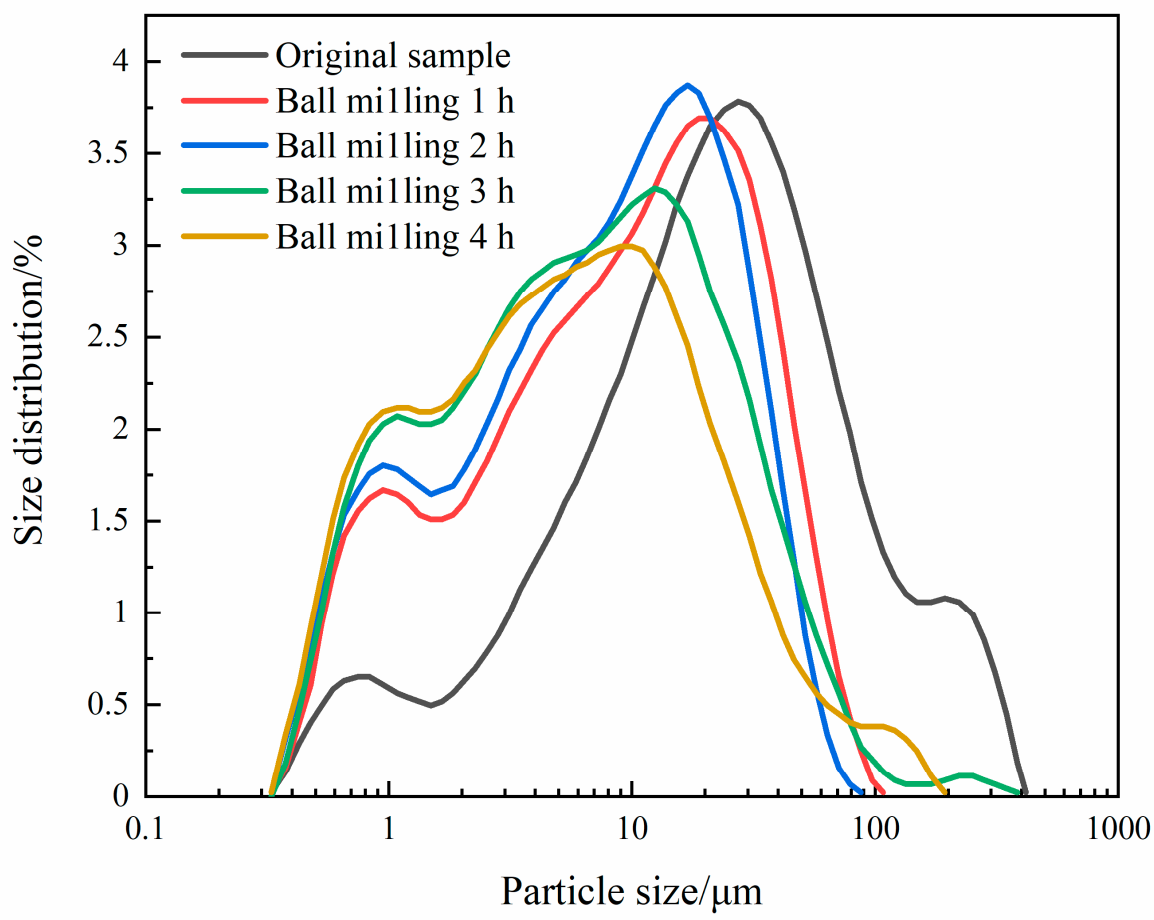

Figure 11. Particle size distributions of non-magnetic tailings obtained from different ball milling times.

Table 9. Particle size parameters of non-magnetic tailings obtained from different ball milling times.

\begin{tabular}{cccccc}
\hline $\begin{array}{c}\text { Particle } \\
\text { Size } / \boldsymbol{\mu m}\end{array}$ & $\begin{array}{c}\text { Original } \\
\text { Sample }\end{array}$ & $\begin{array}{c}\text { Ball Milling } \\
\mathbf{1 ~ h}\end{array}$ & $\begin{array}{c}\text { Ball Milling } \\
\mathbf{2 ~ \mathbf { ~ }}\end{array}$ & $\begin{array}{c}\text { Ball Milling } \\
\mathbf{3 ~ h}\end{array}$ & $\begin{array}{c}\text { Ball Milling } \\
\mathbf{4} \mathbf{~ h}\end{array}$ \\
\hline $\mathrm{D} 10$ & 2.66 & 0.87 & 0.85 & 0.78 & 0.75 \\
$\mathrm{D} 50$ & 21 & 7.67 & 6.52 & 5.22 & 5.10 \\
$\mathrm{D} 90$ & 106.5 & 29.68 & 24.05 & 23.58 & 29.7 \\
$\mathrm{SSA} / \mathrm{g} / \mathrm{cm}^{2}$ & 1.03 & 2.22 & 2.34 & 2.63 & 2.73 \\
\hline
\end{tabular}


According to the Chinese Standard GB/T 175-2007 (Standard for Common Portland cement), the minimum compressive strength of Portland cement at 3 and 28 days should be greater than 17 and $42.5 \mathrm{MPa}$, respectively (GB/T 175-2007). They explored the most suitable mixing ratio of copper slag tailings to replace clinker. They believed that the proportion of copper slag tailings ranges from $6 \%$ to $15 \%$.

Figure 12 shows the changes of the compressive strength and breaking strength versus the clinker content replacement by non-magnetic tailings at 3 and 28 days. It can be seen that the compressive strength of the Portland cement at 3 and 28 days increased from 24.1 to $29.70 \mathrm{MPa}$ and 47 to $50.89 \mathrm{MPa}$, respectively, and the addition of non-magnetic tailings increased from $0 \%$ to $9 \%$. If the amount of non-magnetic tailings is further increased, the compressive strength is decreased. Compared with the $42.5 \mathrm{MPa}$ compressive strength level of common Portland cement strength standard, the compressive strength of the samples at 3 and 28 days are higher. Meanwhile, with the increase in the amount of non-magnetic tailings, the breaking strength at 3 and 28 days changed slightly, and their values were about 5 and $7.5 \mathrm{MPa}$, respectively. All samples meet the 42.5 strength level of common Portland cement strength standard.

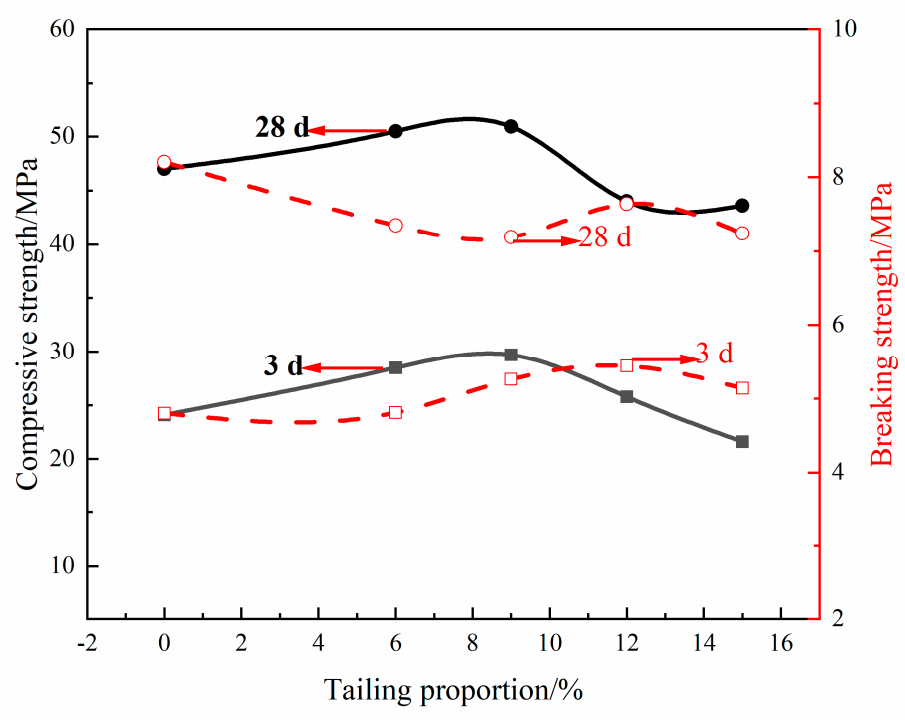

Figure 12. Variations of compressive strength versus the content of cement replacement by nonmagnetic tailings.

\subsection{Balance of Elements in the Proposed Flow Chart}

From the above research, we proposed a stepwise extraction process for the recovery of $\mathrm{Cu}, \mathrm{Fe}, \mathrm{Zn}$ and $\mathrm{Pb}$, and the production of common Portland cement from non-magnetic tailings, as shown in Figure 13. It can be seen that the reason for the increase in the yield of green pellets is the addition of limestone and binder. However, through direct reduction, the sum of dust yield and reduced pellet yield is less than the yield of green pellets. This is because of the loss on ignition of limestone and flotation tailings. Several products were obtained from WCS, Cu concentrate for copper smelting, magnetic concentrate for weather resistance steelmaking and non-magnetic tailings for building construction. The proposed process can recover more than $90 \%$ iron and copper. Meanwhile, the recovery rates of $\mathrm{Zn}$ and $\mathrm{Pb}$ exceed over $90 \%$. Moreover, the proposed process achieves zero tailing emissions. Therefore, WCS can be effectively utilized through this process. 


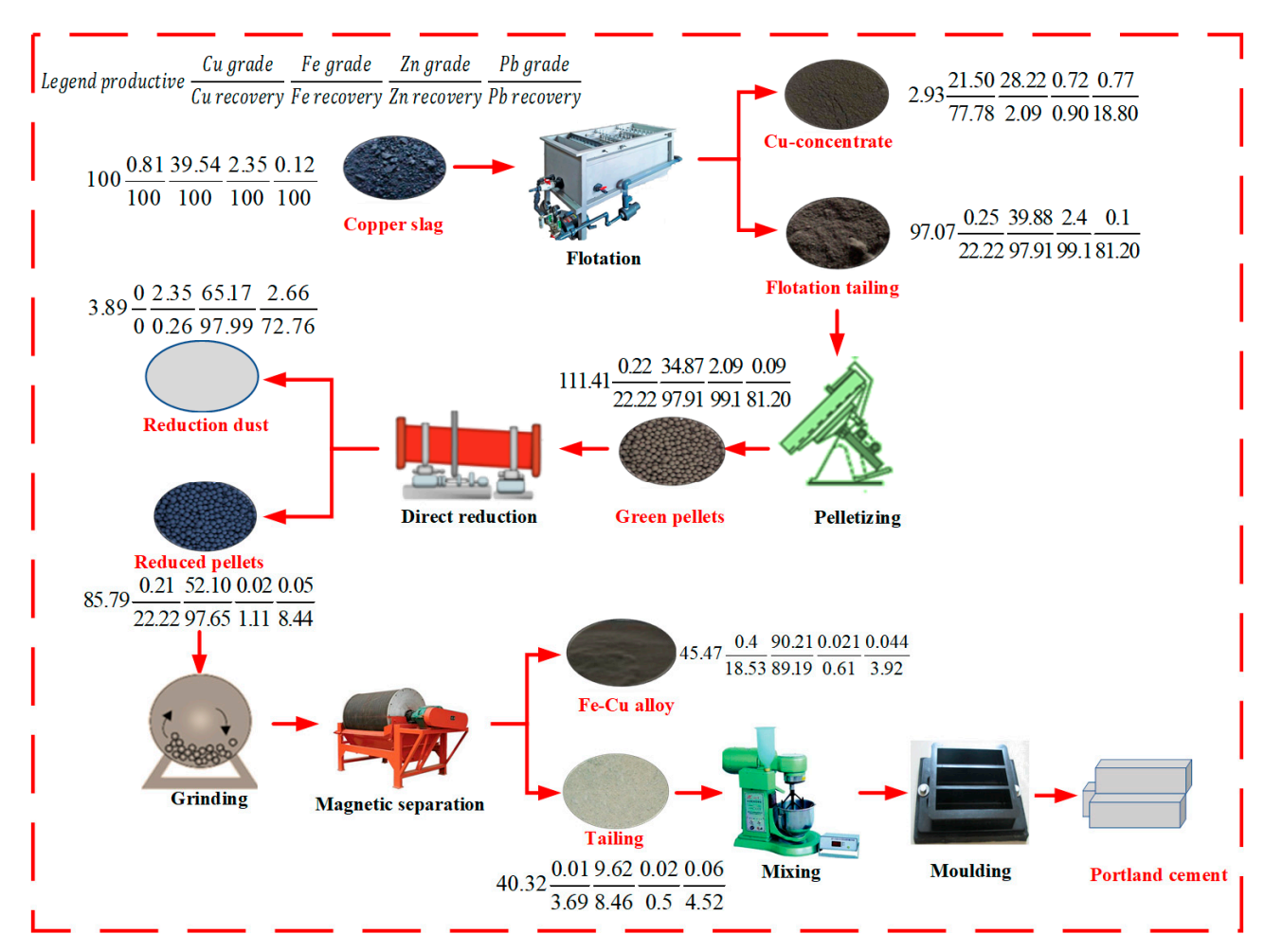

Figure 13. Balance of elements in the proposed flowchart.

\section{Conclusions}

The waste copper slag containing $39.54 \% \mathrm{Fe}$ and $0.81 \% \mathrm{Cu}$ was used as a raw material for recovering valuable elements through stepwise extraction. Under the optimal conditions, four products were obtained, including flotation concentrate, magnetic separation concentrate, zinc-bearing dust and Portland cement. The overall Cy recovery rate of the flotation concentrate is $77.78 \%$, which can reach a copper content of $21.50 \%$, which can be used as a burden for copper smelting. The magnetite concentrate contains $90.21 \%$ of Fe and $0.4 \%$ of $\mathrm{Cu}$ with $91.34 \%$ of iron recovery and $83.14 \%$ of copper recovery, which meets the requirements of weather steelmaking. Meanwhile, the zinc-bearing dust contains $65.17 \%$ of $\mathrm{ZnO}$ and $2.66 \%$ of $\mathrm{PbO}$ with an overall zinc and lead volatilization of $98.89 \%$ and $89.6 \%$, which can be used as a raw material for preparing nano $\mathrm{ZnO}$. The strength of common Portland cement meets the 42.5 strength level standard. The proposed process can provide an alternative method for the effective and green utilization of waste copper slag.

Author Contributions: Methodology, Z.G.; Investigation, S.L. (Siwei Li), T.D. and S.L. (Shenghu Lu); Writing-original draft preparation, S.L. (Siwei Li); Writing—review and editing, S.L. (Siwei Li); Supervision, J.P. and D.Z.; Funding acquisition, Z.G. and D.Z. All authors have read and agreed to the published version of the manuscript.

Funding: This work was financially supported by the Youth natural science foundation China (No. 51904347), Innovation-driven Project of Guangxi Zhuang Autonomous Region (No. AA18242003, No. AA148242003) and the Youth Natural Science Foundation of Hunan Province (No. 2020JJ5726).

Data Availability Statement: Not applicable.

Acknowledgments: The authors would like to thank Co-Innovation Center for Clean and Efficient Utilization of Strategic Metal Mineral Resources of Hunan Province, which supplied us with the facilities and funds to fulfill the experiments. The authors would like to express their gratitude to EditSprings (http:/ / www.editsprings.com) for the expert linguistic services provided.

Conflicts of Interest: The authors declare no conflict of interest. 


\section{References}

1. Sarfo, P.; Das, A.; Wyss, G.; Young, C. Recovery of metal values from copper slag and reuse of residual secondary slag. Waste Manag. 2017, 70, 272-281. [CrossRef]

2. Shen, H.; Forssberg, E. An overview of recovery of metals from slags. Waste Manag. 2003, 23, 933-949. [CrossRef]

3. Heo, J.H.; Kim, B.S.; Park, J.H. Effect of CaO addition on iron recovery from copper smelting slags by solid carbon. Metall. Mater. Trans. B 2013, 44, 1352-1363. [CrossRef]

4. Heo, J.H.; Chung, Y.S.; Park, J.H. Recovery of iron and removal of hazardous elements from waste copper slag via a novel aluminothermic smelting reduction (ASR) process. J. Clean. Prod. 2016, 137, 777-787. [CrossRef]

5. Karwowska, E.; Wojtkowska, M.; Andrzejewska, D. The influence of metal speciation in combustion waste on the efficiency of $\mathrm{Cu}, \mathrm{Pb}, \mathrm{Zn}, \mathrm{Cd}, \mathrm{Ni}$ and $\mathrm{Cr}$ bioleaching in a mixed culture of sulfur-oxidizing and biosurfactant-producing bacteria. J. Hazard Mater. 2015, 299, 35-41. [CrossRef]

6. Saffarzadeh, A.; Shimaoka, T.; Motomura, Y.; Watanabe, K. Characterization study of heavy metal-bearing phases in MSW slag. J. Hazard Mater. 2009, 164, 829-834. [CrossRef]

7. Alp, I.; Deveci, H.; Süngün, H. Utilization of flotation wastes of copper slag as raw material in cement production. J. Hazard Mater. 2008, 159, 390-395. [CrossRef]

8. Durinck, D.; Engstrom, F.; Arnout, S.; Heulens, J.; Jones, P.T.; Bj€orkman, B.; Blanpain, B.; Wollants, P. Hot stage processing of metallurgical slags. Resour. Conserv. Recycl. 2008, 52, 1121-1131. [CrossRef]

9. Shi, C.; Meyer, C.; Behnood, A. Utilization of copper slag in cement and concrete. Resour. Conserv. Recycl. 2008, 52, 1115-1120. [CrossRef]

10. Guo, Z.Q.; Zhu, D.Q.; Pan, J.; Zhang, F. Innovative methodology for comprehensive and harmless utilization of waste copper slag via selective reduction-magnetic separation process. J. Clean. Prod. 2018, 187, 910-922. [CrossRef]

11. Chen, M.; Zeng, G.; Huang, D.; Yang, C.; Lai, C.; Liu, Y.; Xu, P.; Zhang, C.; Wang, J.; Liu, Y.; et al. Degradation of atrazine by a novel Fenton-like process and assessment the influence on the treated soil. J. Hazard Mater. 2016, 312, 184-191. [CrossRef] [PubMed]

12. Kalusuraman, G.; Kumaran, S.; Aslan, M.; Küçükömerog `luc, T.; Siva, I. Use of waste copper slag filled jute fiber reinforced composites for effective erosion prevention. Measurement 2019, 148, 106950. [CrossRef]

13. Potysz, A.; Hullebusch, E.D.; Kierczak, J.; Grybos, M.; Lens, P.N.; Guibaud, G. Copper metallurgical slags-Current knowledge and fate: A review. Crit. Rev. Environ. Sci. Technol. 2015, 45, 2424-2488. [CrossRef]

14. Murari, K.; Siddique, R.; Jain, K. Use of waste copper slag, a sustainable material. J. Mater. Cycles Waste Manag. 2015, 17, 13-26. [CrossRef]

15. Roy, S.; Datta, A.; Rehani, S. Flotation of copper sulphide from copper smelter slag using multiple collectors and their mixtures. Int. J. Miner. Process. 2015, 143, 43-49. [CrossRef]

16. Guo, Z.Q.; Zhu, D.Q.; Pan, J.; Wu, T.J.; Zhang, F. Improving beneficiation of copper and iron from copper slag by modifying the molten copper slag. Metals 2016, 6, 86. [CrossRef]

17. Gargul, K.; Boryczko, B.; Bukowska, A.; Jarosz, P.; Małecki, S. Leaching of lead and copper from flash smelting slag by citric acid. Arch. Civ. Mech. Eng. 2019, 19, 648-656. [CrossRef]

18. Muhammad, K.K.; Joseph, H.; Vivek, A.; Jouni, P.; Mika, H.; Mari, L. Sulfuric acid leaching for capturing value from copper rich converter slag. J. Clean. Prod. 2019, 25, 1005-1013.

19. Nadirov, R.K.; Syzdykova, L.I.; Zhussupova, A.K.; Usserbaev, M.T. Recovery of value metals from copper smelter slag by ammonium chloride treatment. Int. J. Miner. Process 2013, 124, 145-149. [CrossRef]

20. Mikoda, B.; Potysz, A.; Kmiecik, E. Bacterial leaching of critical metal values from polish copper metallurgical slags using acidithiobacillus thiooxidans. J. Environ. Manag. 2019, 236, 436-445. [CrossRef]

21. Li, S.W.; Pan, J.; Zhu, D.Q.; Guo, Z.Q.; Xu, J.W.; Chou, J.L. A novel process to upgrade the copper slag by direct reduction-magnetic separation with the addition of $\mathrm{Na}_{2} \mathrm{CO}_{3}$ and CaO. Powder Technol. 2019, 347, 159-169. [CrossRef]

22. Zhou, S.W.; Wei, Y.G.; Li, B.; Wang, H. Cleaner recycling of iron from waste copper slag by using walnut shell char as green reductant. J. Clean. Prod. 2019, 217, 423-431. [CrossRef]

23. Guo, Z.Q.; Pan, J.; Zhu, D.Q.; Zhang, F. Green and efficient utilization of waste ferric-oxide desulfurizer to clean waste copper slag by the smelting reduction-sulfurizing process. J. Clean. Prod. 2018, 199, 891-899. [CrossRef]

24. Keiran, H.; Hürman, E.R.; Pekka, T.; Ari, J. Upgrading copper slag cleaning tailings for re-use. Miner. Eng. $2019,133,35-42$.

25. Zhou, X.L.; Zhu, D.Q.; Pan, J.; Wu, T.J. Utilization of waste copper slag to produce directly reduced iron for weathering resistant steel. ISIJ 2015, 55, 1347-1352.

26. Zhu, D.Q.; Xu, J.W.; Guo, Z.Q.; Pan, J.; Li, S.W.; Pan, L.T.; Yang, C.C. Synergetic utilization of copper slag and ferruginous manganese ore via co-reduction followed by magnetic separation process. J. Clean. Prod. 2020, 250, 119462. [CrossRef] 
27. Shaker, F.; Rashad, A.; Allam, M. Properties of concrete incorporating locally produced Portland limestone cement. Ain Shams Eng. J. 2018, 9, 2301-2309. [CrossRef]

28. Huang, Y.K.; Geng, Y.B.; Han, G.H.; Cao, Y.J.; Peng, W.J.; Zhu, X.F.; Zhang, T.A.; Dou, Z.H. A perspective of stepwise utilization of hazardous zinc plant purification residue based in selective alkaline leaching of zinc. J. Hazard Mater. 2020, $389,122090$. [CrossRef]

29. Zhang, H.X.; Yang, Y.T.; Liu, X.J. Study of cadmium-doped zinc oxide nanocrystals with composition and size dependent band gaps. Chin. J. Chem. Phys. 2018, 31, 197-202. [CrossRef] 